\title{
Synthesis, spectra and crystal structure of $(E)-(\mathrm{CO})_{2}(\mathrm{NO}) \mathrm{Cr}\left[\left(\eta^{5}-\mathrm{C}_{5} \mathrm{H}_{4}\right)-\mathrm{CH}=\mathrm{CH}\left(\eta^{5}-\mathrm{C}_{5} \mathrm{H}_{4}\right)\right] \mathrm{Cr}(\mathrm{CO})_{2}(\mathrm{NO})$
}

\author{
Yu-Pin Wang a,*, Xen-Hum Lui ${ }^{\text {a }}$, Bi-Son Lin ${ }^{\text {a }}$, Wei-Der Tang ${ }^{\text {a }}$, Tso-Shen Lin ${ }^{\text {a, }}$ \\ Jen-Hai Liaw ${ }^{\text {a }}$, Yu Wang ${ }^{\text {b }}$, Yi-Hung Liu ${ }^{\mathrm{b}}$ \\ a Department of Chemistry, Tunghai University, Taichung, Taiwan, ROC \\ ${ }^{\mathrm{b}}$ Department of Chemistry, National Taiwan University, Taipei, Taiwan, ROC
}

Received 14 April 1998; received in revised form 19 September 1998

\begin{abstract}
Compounds 1,2-bis[( $\eta^{5}$-cyclopentadienyl)dicarbonylnitrosylchromium $]$ ethene (7) (hereafter called 1,2-dicynichrodenylethene) and 1,2-diferrocenylethene (10) were prepared from formylcynichrodene (3) and formylferrocene (9), respectively, via the McMurry's low-valent titanium coupling method. Compounds $\left(\eta^{5}\right.$-vinylcyclopentadienyl)dicarbonylnitrosylchromium (6) and vinylferrocene (11) were obtained by the dehydration of the corresponding alcohols. The structure of 7 was solved by an X-ray diffraction study: space group, $P 2_{1} / c$; monoclinic; $a=6.379(5), b=11.295(3)$ and $c=11.9352(24) ; Z=2$. It turns out that compound 7 adopts a transoid conformation at the ethenylene bridge and the two cyclopentadienyl rings are coplanar. The nitrosyl group in each cynichrodenyl moiety of $\mathbf{7}$ is located at the side towards the corresponding ethenylene carbon atom with a twist angle of $46.5^{\circ}$. The chemical shifts of $\mathrm{H}(2)-\mathrm{H}(5)$ protons and $\mathrm{C}(2)-\mathrm{C}(5)$ carbon atoms of a series of vinyl derivatives of compounds bearing cyclopentadienyl rings have been assigned using two-dimensional HetCOR-NMR spectroscopy. For the derivatives of cynichrodene (1) and ferrocene, it was found that the shielding of $C(2,5)$ and $C(3,4)$ carbon atoms is parallel to the shielding of the ortho- and para-carbon atoms of benzene derivatives. The electron density distribution in the cyclopentadienyl ring is discussed on the basis of ${ }^{13} \mathrm{C}$-NMR data. Surprisingly, the vinyl group donates electron density to the adjacent cynichrodene moieties rather than withdraws from them. (C) 1999 Elsevier Science S.A. All rights reserved.
\end{abstract}

Keywords: Chromium; Synthesis; Spectra; Crystal structure

\section{Introduction}

Earlier [1,2], we reported the unequivocal assignments of $\mathrm{C}(2,5)$ and $\mathrm{C}(3,4)$ on the $\mathrm{Cp}$ ring of cynichrodene (1) derivatives bearing electron-donating or electron-withdrawing substituent in ${ }^{13} \mathrm{C}-\mathrm{NMR}$ spectra. For derivatives with electron-donating substituents, an analogy was observed between the shielding of $C(2,5)$ and $\mathrm{C}(3,4)$ carbon atoms of cynichrodene 1 derivatives and ferrocene derivatives and that of the ortho-

* Corresponding author. Fax: + 886-4-359-96851. and para-carbon atoms of benzene derivatives. For derivatives bearing electron-withdrawing substituents, the opposite correlation on the assignments was observed between cynichrodene derivatives and the derivatives of ferrocene and benzene. The high-field and low-field chemical shifts are assigned to $C(3,4)$ and $\mathrm{C}(2,5)$, respectively, in the case of cynichrodene derivatives bearing electron-withdrawing groups, while the opposite assignment was made for the ferrocene derivatives. This amazing finding prompted us to study 6-7 and 10-11, compounds containing vinyl moiety, a group capable of being either electron-donating or electron-withdrawing.

Several methods have been employed to couple the 
carbonyl groups to yield orefins [3,4]. However, the applications to organometallic compounds are limited [5]. Herein, we report the preparations of $\mathbf{7}$ and $\mathbf{1 0}$ via the McMurry's low valent titanium method and the crystal structure of $(E)-(\mathrm{CO})_{2}(\mathrm{NO}) \mathrm{Cr}(\mathrm{Cp}-$ $\mathrm{CH}=\mathrm{CHCp}) \mathrm{Cr}(\mathrm{NO})(\mathrm{CO})_{2}$ (7). Spectral comparison between benzene, ferrocene and cynichrodene derivatives bearing corresponding substituents is also included.

\section{Experimental details}

All the syntheses were carried out under nitrogen by the use of Schlenk techniques. Traces of oxygen in the nitrogen were removed with BASF catalyst and the deoxygenated nitrogen was dried over molecular sieves $(3 \AA)$ and $\mathrm{P}_{2} \mathrm{O}_{5}$. Hexane, pentane, benzene, and dichloromethane were dried over calcium hydride and freshly distilled under nitrogen. Diethyl ether was dried over sodium and re-distilled under nitrogen from sodium-benzophenone ketyl. All the other solvents were used as commercially obtained.

Column chromatography was carried out under nitrogen with Merck Kiesel-gel 60. The silica gel was heated with a heat gun during mixing in a rotary evaporator attached to a vacuum pump for $2 \mathrm{~h}$ to remove water and oxygen. The silica gel was then stored under nitrogen until use. Compounds 3 and $\mathbf{9}$ were prepared according to the literature procedures $[6,7]$.

${ }^{1} \mathrm{H}$ - and ${ }^{13} \mathrm{C}-\mathrm{NMR}$ were acquired on a Varian Unity-300 spectrometer. Chemical shifts were referenced to tetramethylsilane. IR spectra were recorded with a Perkin-Elmer Fourier transform IR 1725X spectrophotomer. Microanalyses were carried out by the Microanalytic Laboratory of the National Chung Hsing University.

\subsection{Preparation of ( $\eta^{5}$-vinyleyclopentadienyl) dicarbonylnitrosylchromium (6)}

This compound was prepared according to Mintz and Rausch [8] with minor modifications. [ $\eta^{5}-(1-\mathrm{Hy}-$ droxyethyl)cyclopentadienyl]dicarbonylnitrosy-l-chromium (8) $(0.54 \mathrm{~g}, 2.2 \mathrm{mmol}), 5 \mathrm{mg}$ of hydroquinone, and $0.05 \mathrm{~g}$ of $p$-toluenesulfonic acid were dissolved in $50 \mathrm{ml}$ of benzene. The mixture was refluxed for 1.25 $\mathrm{h}$, then $100 \mathrm{ml}$ of dichloromethane was added. The solution was washed with distilled water and then dried with anhydrous magnesium sulfate. After the solution was filtered and concentrated, $0.42 \mathrm{~g}$ of a residue of $6(84 \%)$ was obtained. An analytical sample was prepared from centrafugal TLC (hexane:benzene (1:1)).

Proton-NMR $\left(\mathrm{CDCl}_{3}\right): \delta$ (relative intensity, multi- plicity, assignment): $5.01(2 \mathrm{H}, \mathrm{t}, \mathrm{Cp} \mathrm{H}(3,4)) ; 5.15$ $\left(1 \mathrm{H}, \mathrm{dd}, \mathrm{H}_{\mathrm{B}}, J_{\mathrm{AB}}=3.3, J_{\mathrm{BX}}=11\right) ; 5.20(2 \mathrm{H}, \mathrm{t}, \mathrm{Cp}$ $\mathrm{H}(2,5)) ; 5.44\left(1 \mathrm{H}, \mathrm{dd}, \mathrm{H}_{\mathrm{A}}, J_{\mathrm{AX}}=17.7\right) ; 6.22(1 \mathrm{H}, \mathrm{dd}$, $\left.\mathrm{H}_{\mathrm{x}}\right) \cdot{ }^{13} \mathrm{C}-\mathrm{NMR}\left(\mathrm{CDCl}_{3}\right): \delta$ (assignment): $88.13(\mathrm{Cp}$, $\mathrm{C}(2,5)) ; 89.74$ (Cp, C(3,4)), 108.31 (Cp, C(1)); 115.13 $\left(=\mathrm{CH}_{2}\right) ; 128.70(-\mathrm{CH}=) ; 236.97(\mathrm{Cr}-\mathrm{C} \equiv \mathrm{O}) . \mathrm{IR}(\mathrm{KBr})$ : $v\left(\mathrm{~cm}^{-1}\right)$ (intensity): 2020 (vs), 1946 (vs), 1696 (vs), $628(\mathrm{~m})$.

\subsection{Preparation of (E)-1,2-dicynichrodenylethene (7)}

Titanium tetrachloride $(3.30 \mathrm{ml}, 30 \mathrm{mmol})$ was added into a Schlenk tube containing lithium alu-

Table 1

Summary of crystal data and intensity collection of $7^{\text {a }}$

\begin{tabular}{|c|c|}
\hline Empirical formula & $\mathrm{C}_{16} \mathrm{H}_{10} \mathrm{O}_{6} \mathrm{~N}_{2} \mathrm{Cr}_{2}$ \\
\hline Formula weight & 430.25 \\
\hline Diffractometer used & Nonius \\
\hline Space group & $P 2_{1} / c ;$ monoclinic \\
\hline$a(\AA)$ & $6.379(5)$ \\
\hline$b(\AA)$ & $11.295(3)$ \\
\hline$c(\AA)$ & $11.9352(24)$ \\
\hline$\beta\left(^{\circ}\right)$ & $99.17(4)$ \\
\hline Volume $\left(\AA^{3}\right)$ & $849.0(7)$ \\
\hline$Z$ & 2 \\
\hline Density (calculated) $\left(\mathrm{g} \mathrm{cm}^{-3}\right)$ & 1.683 \\
\hline$\lambda(\AA)$ & 0.7093 \\
\hline$F(000)$ & 432 \\
\hline Number of reflections for indexing & $25\left(14.44^{\circ} \leqq 2 \theta \leqq 26.00^{\circ}\right)$ \\
\hline Scan type & $0-2 \theta$ \\
\hline Scan width $\left(^{\circ}\right)$ & $2(0.70+0.35 \tan (\theta))$ \\
\hline Scan speed $\left({ }^{\circ} \min ^{-1}\right)$ & $2.06-8.24$ \\
\hline $2 \theta$ maximum $\left(^{\circ}\right)$ & 50 \\
\hline$h, k, l$ ranges & $(-7,7),(0,13),(0,14)$ \\
\hline$\mu\left(\mathrm{cm}^{-1}\right)$ & 12.833 \\
\hline Crystal size (mm) & $0.05 \times 0.20 \times 0.50$ \\
\hline Transmission & $0.865,1.000$ \\
\hline Temperature (K) & 298 \\
\hline Number of measured reflections & 1492 \\
\hline $\begin{array}{l}\text { Number of observed reflections } \\
\qquad(I>2.0 \sigma(I))\end{array}$ & 1071 \\
\hline Number of unique reflections & 1492 \\
\hline$R_{f}, R_{w}$ & $0.035,0.027$ \\
\hline Goodness-of-fit & 1.86 \\
\hline Refinement program & NRCVAX \\
\hline Number of atoms & 18 \\
\hline Number of parameters refined & $\begin{array}{l}138 \text { ( } 1071 \text { out of } 1492 \\
\text { reflections) }\end{array}$ \\
\hline Minimize function & $\operatorname{Sum}\left(w\left|F_{\mathrm{o}}-F_{\mathrm{c}}\right|^{2}\right)$ \\
\hline Weights scheme & $\left(1 / \sigma\left(F_{\mathrm{o}}\right)\right)^{2}$ \\
\hline$(\Delta / \sigma) \max$ & 0.0085 \\
\hline$\left(D\right.$-map) $\max , \min \left(\mathrm{e} \AA^{-3}\right)$ & $-0.260,0.380$ \\
\hline
\end{tabular}

${ }^{\mathrm{a}} R_{f}=\operatorname{Sum}\left(F_{\mathrm{o}}-F_{\mathrm{c}}\right) / \operatorname{Sum}\left(F_{\mathrm{o}}\right) ; \quad R_{w}=\operatorname{Sqrt}\left[\operatorname{Sum}\left(w\left(F_{\mathrm{o}}-F_{\mathrm{c}}\right)^{2}\right) / \operatorname{Sum}\left(w F_{\mathrm{o}}^{2}\right)\right] ;$ goodness-of-fit $=\operatorname{Sqrt}\left[\operatorname{Sum}\left(w\left(F_{\mathrm{o}}-F_{\mathrm{c}}\right)^{2} /(\right.\right.$ no. of reflections - no. of parameters)]. 
Table 2

The contracted 2D HetCOR spectra of 2-7

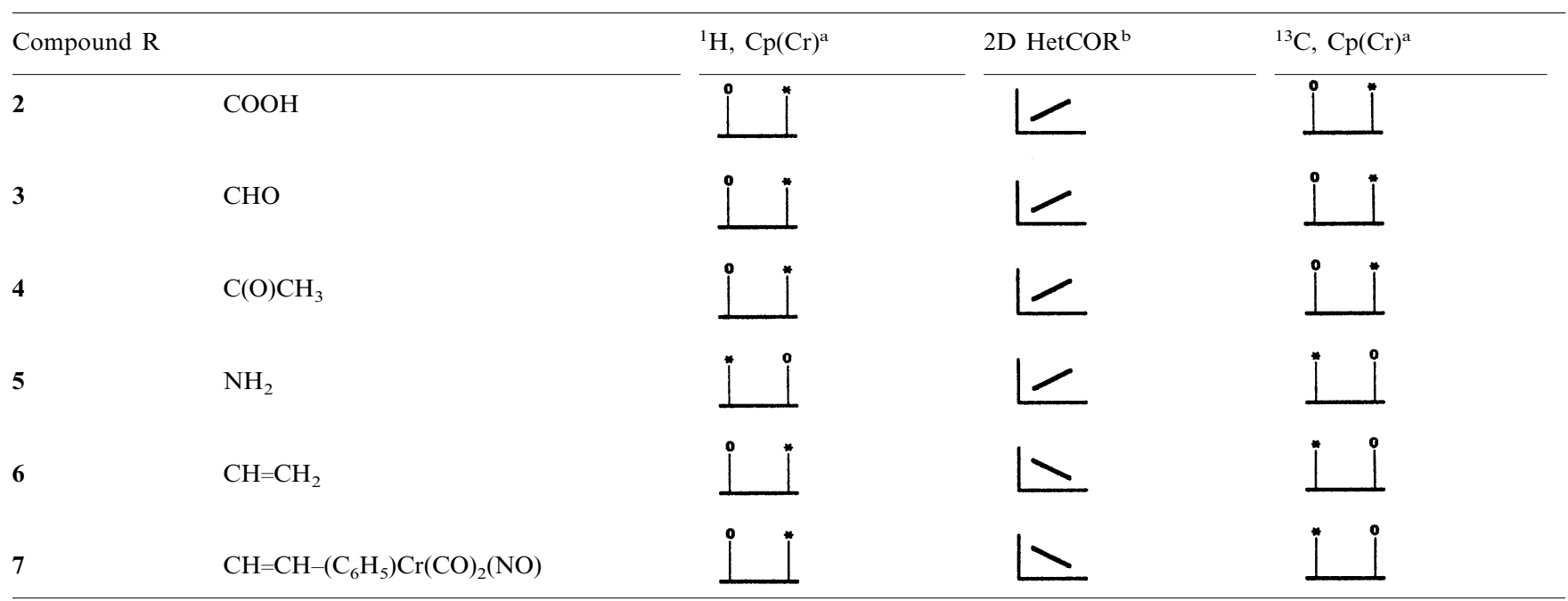

a $\bigcirc,(2,5) ; *,(3,4)$; the magnetic field increases towards the right.

${ }^{\mathrm{b}}$ The magnetic fields of ${ }^{1} \mathrm{H}$ - and ${ }^{13} \mathrm{C}-\mathrm{NMR}$ spectra increase towards the right and upper side respectively.

minium hydride $(0.57 \mathrm{~g}, 15 \mathrm{mmol})$ at $0^{\circ} \mathrm{C}$. The temperature was slowly raised to $90^{\circ} \mathrm{C}$ and held for $12 \mathrm{~h}$ with stirring. After cooling down to $0^{\circ} \mathrm{C}, 100 \mathrm{ml}$ of tetrahydrofuran and formylcynichrodene (3) $(0.92 \mathrm{~g}, 4.0$ $\mathrm{mmol}$ ) were added into the residue. The reaction mixture was heated to $55^{\circ} \mathrm{C}$ and held for $16 \mathrm{~h}$ before cooling to $0^{\circ} \mathrm{C}$, then $50 \mathrm{ml}$ of a saturated potassium carbonate aqueous solution was added in slowly. Thereupon the reaction mixture was extracted with three $50 \mathrm{ml}$ portions of dichloromethane. The combined extracts were washed three times with distilled water and dried with anhydrous magnesium sulfate. The solution was filtered and concentrated to a residue. The residue was dissolved in $30 \mathrm{ml}$ of dichloromethane. Three grams of silica gel were added to the solution, and the solvent was then removed under vacuum. The residue was added to a dry-packed column $(2.0 \times 30$ $\mathrm{cm})$ of silica gel. Elution of the column with hexane:benzene (3:1) gave two bands. The first band was unidentified. After removal of solvent, the second (red) band gave $(E)$-1,2-dicynichrodenylethene (7) $(0.31 \mathrm{~g}$, $36 \%$ ). An analytical sample (m.p. $186.5^{\circ} \mathrm{C}$ ) was prepared by recrystallization using the solvent evaporation method from pentane:dichloromethane $(5: 1)$ at $0^{\circ} \mathrm{C}$.

Anal. Found: $\mathrm{C}, \quad 44.53 ; \mathrm{H}, \quad 2.46 ; \mathrm{N}, 6.66$. $\mathrm{C}_{16} \mathrm{H}_{10} \mathrm{Cr}_{2} \mathrm{~N}_{2} \mathrm{O}_{6}$ Calc.: C, 44.67; H, 2.34; N, 6.51\%. Proton-NMR $\left(\mathrm{CDCl}_{3}\right): \delta$ (relative intensity, multiplicity, assignment): $5.05(2 \mathrm{H}, \mathrm{t}, \mathrm{Cp} \mathrm{H}(3,4)) ; 5.25(2 \mathrm{H}, \mathrm{t}$, $\mathrm{Cp} \mathrm{H}(2,5)) ; 6.31(2 \mathrm{H}, \mathrm{s},-\mathrm{CH}=) .{ }^{13} \mathrm{C}-\mathrm{NMR}\left(\mathrm{CDCl}_{3}\right): \delta$ (assignment): 88.57 (Cp, C(2,5)); $89.93(\mathrm{Cp}, \mathrm{C}(3,4))$, $106.72(\mathrm{Cp}, \mathrm{C}(1)) ; 121.59(-\mathrm{CH}=) ; 236.70(\mathrm{Cr}-\mathrm{C} \equiv \mathrm{O})$.
$\operatorname{IR}(\mathrm{KBr}): v\left(\mathrm{~cm}^{-1}\right)$ (intensity): 2010 (vs), 1932 (vs), 1682 (vs), $644(\mathrm{~m})$. Mass spectrum: $m / z: 430\left(\mathrm{M}^{+}\right)$.

\subsection{Preparation of (E)-1,2-diferrocenylethene (10)}

To a solution of titanium trichloride $(2.80 \mathrm{~g}, 18$ $\mathrm{mmol})$ in tetrahydrofuran, lithium aluminium hydride $(0.34 \mathrm{~g}, 9.0 \mathrm{mmol})$ was added in an ice salt bath. After stirring for $30 \mathrm{~min}$, formylferrocene (9) $(1.00 \mathrm{~g}, 4.6$ $\mathrm{mmol}$ ) in $20 \mathrm{ml}$ of tetrahydrofuran was added into the deep black solution. After stirring for $3 \mathrm{~h}$ at room temperature, $20 \mathrm{ml}$ of hydrochloric acid $(4 \mathrm{~N})$ was added. The reaction mixture was then extracted with three $50 \mathrm{ml}$ portions of dichloromethane. The combined extracts were washed three times with distilled water and dried with anhydrous magnesium sulfate. The solution was filtered. Ten grams of silica gel were added and the solvent was then removed under vacuum. The residue was added to a dry-packed column $(2.0 \times 10$ $\mathrm{cm})$ of silica. Elution of the column with hexane/benzene (1:1) gave two bands. The first band was unidentified. After removal of solvent under vacuum, the second (orange) band gave $(E)(\mathbf{1 0})$ and $(Z)$-1,2-diferrocenylethene with a ratio of $3.5: 1(0.47 \mathrm{~g}, 25 \%)$. An analytical sample of $\mathbf{1 0}$ was prepared by recrystallization using the solvent evaporation method from hexane:dichloromethane $(5: 1)$ at $0^{\circ} \mathrm{C}$.

Proton-NMR $\left(\mathrm{CDCl}_{3}\right): \delta$ (relative intensity, multiplicity, assignment): $4.12\left(10 \mathrm{H}, \mathrm{s}, \mathrm{Cp}^{2}(\mathrm{Fe})\right) ; 4.24(4 \mathrm{H}, \mathrm{t}$, $\left.\mathrm{Cp}^{1}(\mathrm{Fe}) \mathrm{H}(3,4)\right) ; 4.38\left(4 \mathrm{H}, \mathrm{t}, \mathrm{Cp}^{1}(\mathrm{Fe}) \mathrm{H}(2,5)\right) ; 6.41(2 \mathrm{H}$, 

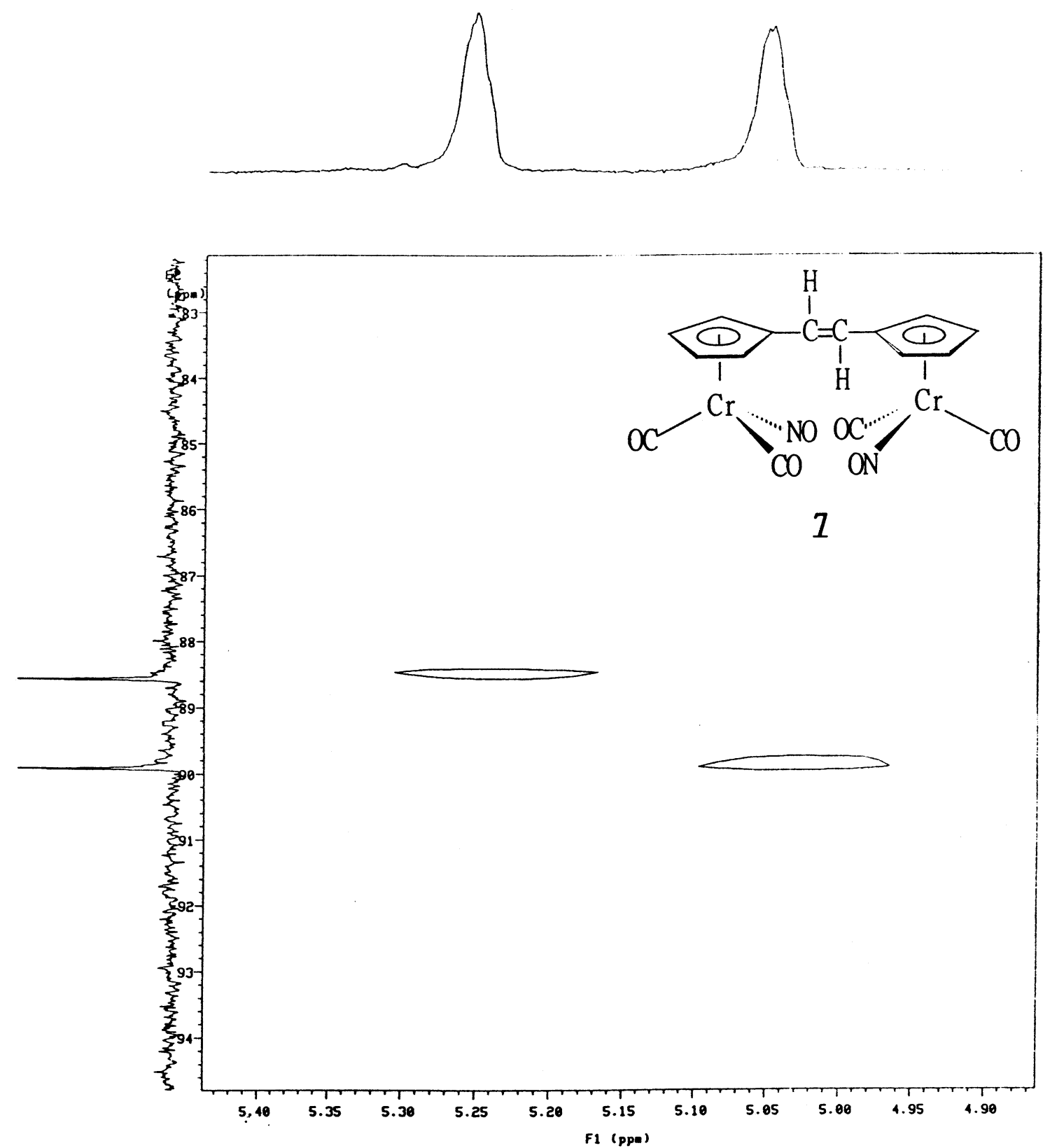

Fig. 1. 2D ${ }^{1} \mathrm{H}\left\{{ }^{13} \mathrm{C}\right)$-HetCOR spectrum of 7 in $\mathrm{CDCl}_{3}$.

$\mathrm{s},-\mathrm{CH}=) .{ }^{13} \mathrm{C}-\mathrm{NMR}\left(\mathrm{CDCl}_{3}\right): \delta$ (assignment): 69.16 $\left(\mathrm{Cp}^{2}(\mathrm{Fe})\right) ; 66.21 \quad\left(\mathrm{Cp}^{1}(\mathrm{Fe}), \mathrm{C}(2,5)\right) ; 68.54 \quad\left(\mathrm{Cp}^{1}(\mathrm{Fe})\right.$, $\mathrm{C}(3,4)) ; \quad 84.33 \quad\left(\mathrm{Cp}^{1}(\mathrm{Fe}), \quad \mathrm{C}(1)\right) ; \quad 123.63 \quad(-\mathrm{CH}=)$. IR(KBr): $v\left(\mathrm{~cm}^{-1}\right)$ (intensity): $1103(\mathrm{w}), 809$ (m), 678 (s).

\subsection{Preparation of vinylferrocene (11)}

The preparation of vinylferrocene compound $\mathbf{1 1}$ was previously reported by Rausch and Seigel [9]. However, a more reliable method is described as following. (1-Hydroxyethyl)ferrocene $(0.52 \mathrm{~g}, 2.24 \mathrm{mmol})$, anhydrous cupric sulfate ( $3 \mathrm{~g}, 18.73 \mathrm{mmol})$, and $5 \mathrm{mg}$ of hydroquinone were dissolved in $100 \mathrm{ml}$ of toluene. The mixture was refluxed for $45 \mathrm{~min}$ and then cooled to room temperature. After the filtration the solvent was removed under vacuum. The residue was extracted with ether and dried with anhydrous magnesium sulfate. The solution was filtered, concentrated to $50 \mathrm{ml}$ under vacuum. The residue was added to a dry-packed column $(1.8 \times 9 \mathrm{~cm})$ of silica gel. Elution of the column with hexane gave an orange band which upon removal of the solvent gave vinylferrocene (11) $(0.40 \mathrm{~g}, 84 \%)$.

Proton-NMR $\left(\mathrm{CDCl}_{3}\right): \delta$ (relative intensity, multiplicity, assignment): $4.11\left(\mathrm{Cp}^{2}\right) ; 4.21\left(2 \mathrm{H}, \mathrm{t}, \mathrm{Cp}^{1}\right.$ $\mathrm{H}(3,4)) ; 4.36\left(2 \mathrm{H}, \mathrm{t}, \mathrm{Cp}^{1} \mathrm{H}(2,5)\right) ; 5.03\left(1 \mathrm{H}, \mathrm{dd}, \mathrm{H}_{\mathrm{B}}\right.$, $\left.J_{\mathrm{AB}}=3.3, J_{\mathrm{BX}}=10.8\right) ; 5.34\left(1 \mathrm{H}, \mathrm{dd}, \mathrm{H}_{\mathrm{A}}, J_{\mathrm{AX}}=16.8\right)$; $6.46\left(1 \mathrm{H}, \mathrm{dd}, \mathrm{H}_{\mathrm{x}}\right) \cdot{ }^{13} \mathrm{C}-\mathrm{NMR}\left(\mathrm{CDCl}_{3}\right): \delta$ (assignment): 
Table 3

${ }^{1} \mathrm{H}-\mathrm{NMR}$ chemical shifts of selected monosubstituted cynichrodene ${ }^{\mathrm{a}}$, ferrocene ${ }^{\mathrm{b}}$ and benzene $\mathrm{e}^{\mathrm{c}}$ from tetramethylsilane and $\Delta^{\mathrm{d}}$

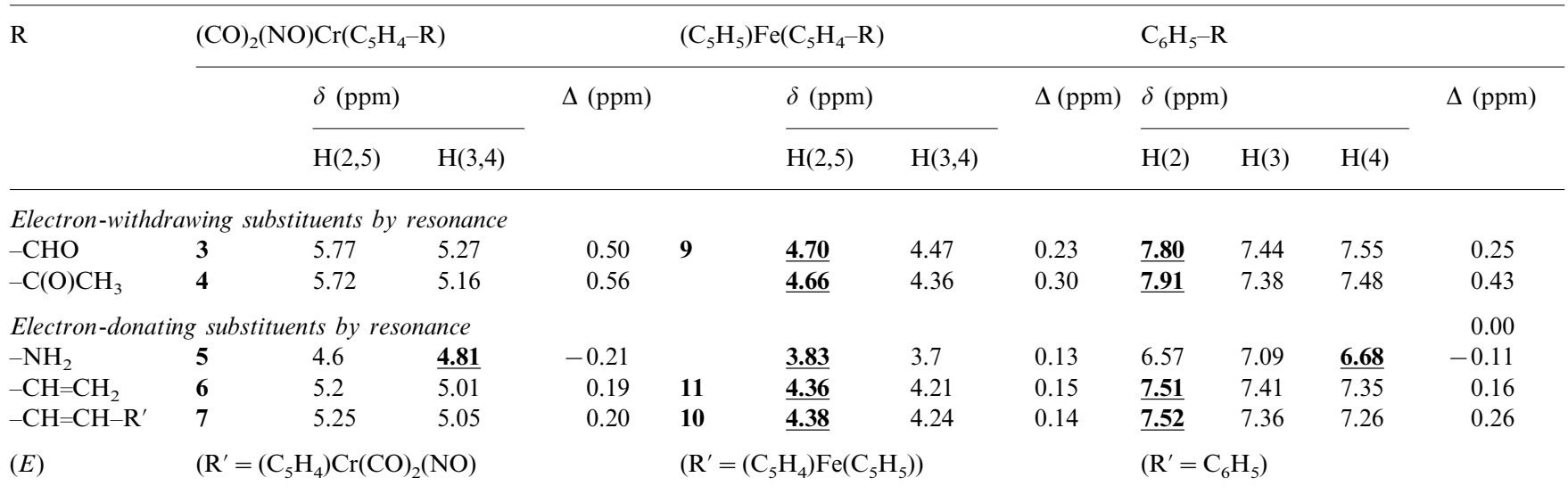

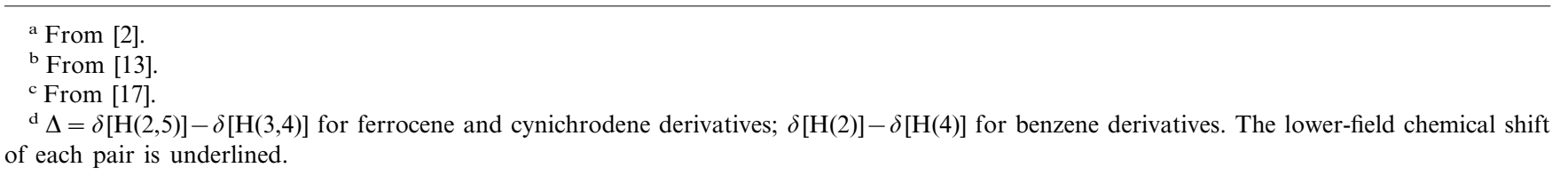

Table 4

${ }^{13} \mathrm{C}-\mathrm{NMR}$ chemical shifts of selected monosubstituted cynichrodene ${ }^{\mathrm{a}}$, ferrocene $\mathrm{e}^{\mathrm{b}}$ and benzene ${ }^{\mathrm{c}}$ from tetramethylsilane and $\Delta^{\mathrm{d}}$

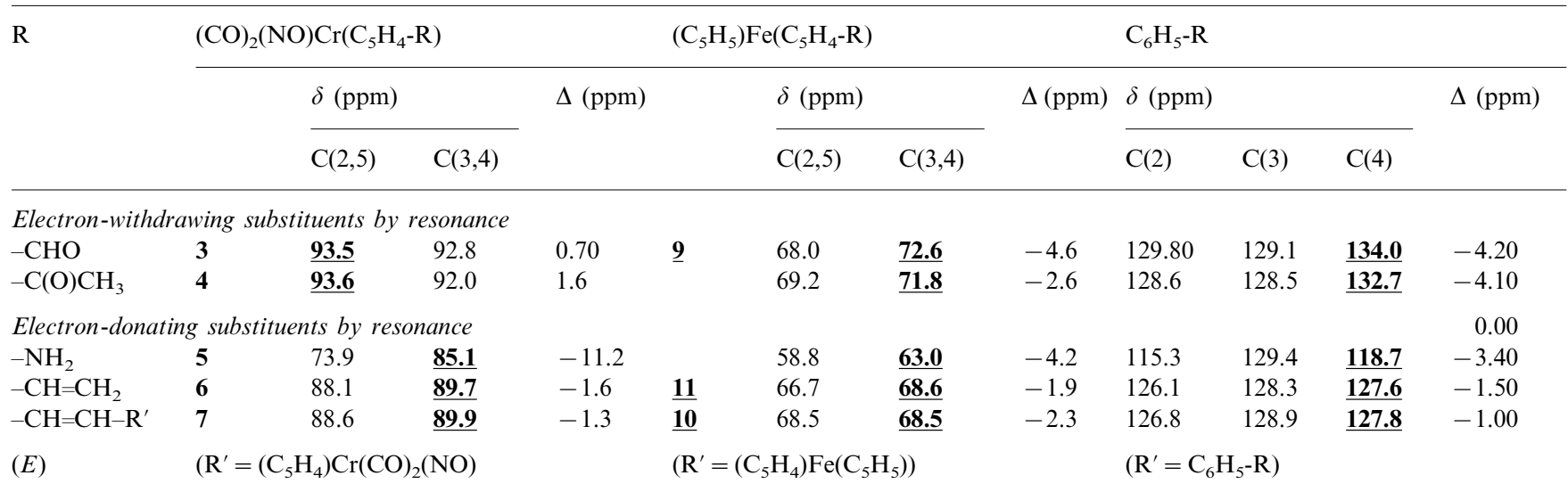

\footnotetext{
${ }^{\text {a }}$ From $[2,18]$.

${ }^{\mathrm{b}}$ From [14].

${ }^{\mathrm{c}}$ From $[17,19]$.

${ }^{\mathrm{d}} \Delta=\delta[\mathrm{C}(2,5)]-\delta[\mathrm{C}(3,4)]$ for ferrocene and cynichrodene derivatives; $\delta[\mathrm{C}(2)]-\delta[\mathrm{C}(4)]$ for benzene derivatives. The lower-field chemical shift of each pair is underlined.
}

$63.53\left(\mathrm{Cp}^{1}, \mathrm{C}(1)\right) ; 66.69\left(\mathrm{Cp}^{1}, \mathrm{C}(2,5)\right) ; 68.63\left(\mathrm{Cp}^{1}\right.$, $\mathrm{C}(3,4)) ; \quad 69.21 \quad\left(\mathrm{Cp}^{2}(\mathrm{Fe})\right) ; \quad 111.02 \quad\left(=\mathrm{CH}_{2}\right) ; 134.63$ $(-\mathrm{CH}=)$.

\subsection{X-ray diffraction analysis of $\mathbf{7}$}

The intensity data were collected on a CAD-4 diffractomer with a graphite monochromator $\left(\mathrm{Mo}-\mathrm{K}_{\alpha}\right.$ radiation). $\theta-2 \theta$ scan data were collected at room temperature $\left(24^{\circ} \mathrm{C}\right)$. The data were corrected for absorption, Lorentz and polarization effects. The absorption correction is according to the empirical psi rotation. The details of crystal data and intensity collection are summarized in Table 1.

The structure was solved by direct methods and was refined by full matrix least squares refinement based on $F$ values. All of the non-hydrogen atoms were refined with anisotropic thermal parameters. All of the hydrogen atoms were positioned at calculated coordinates with a fixed isotropic thermal parameter $(U=U$ (attached atom) $+0.01 \AA^{2}$ ). Atomic scattering factors and corrections for anomalous dispersion were from [10]. All calculations were performed on a DEC alpha workstation using the NRCVAX programs [11].

\section{Results and discussion}

Acid-catalyzed dehydration of alcohol $\mathbf{8}$ in refluxing benzene, using $p$-toluene sulfonic acid, on the presence 
of hydroquinone as a radical inhibitor, gave olefin $\mathbf{6}$ in yield as high as $84 \%$. Using anhydrous cupric sulfate instead of $p$-toluene sulfonic acid, vinylferrocene (11) was obtained from the corresponding alcohol. By reacting with low-valent titanium coupling reagent, prepared from two equivalents of titanium tetrachloride and one equivalent of lithium aluminum chloride, formylcynichrodene (3) was transformed into 7 in $36 \%$ yield. An analogous method using titanium trichloride as coupling agent was employed to prepare compound $\mathbf{1 0}$ from $\mathbf{9}$ with $20 \%$ yield.

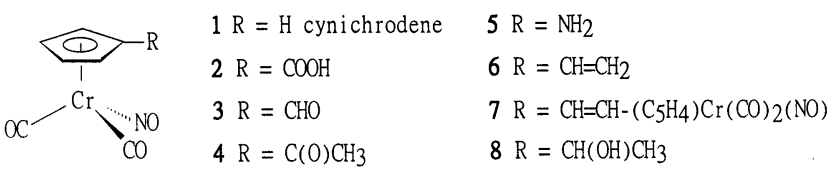

7

$\mathrm{R}=\mathrm{H}$ ferrocene

$9 \mathrm{R}=\mathrm{CHO}$

$10 \mathrm{R}=\mathrm{CH}=\mathrm{CH}-\mathrm{Fc}$

$11 \mathrm{R}=\mathrm{CH}=\mathrm{CH}_{2}$
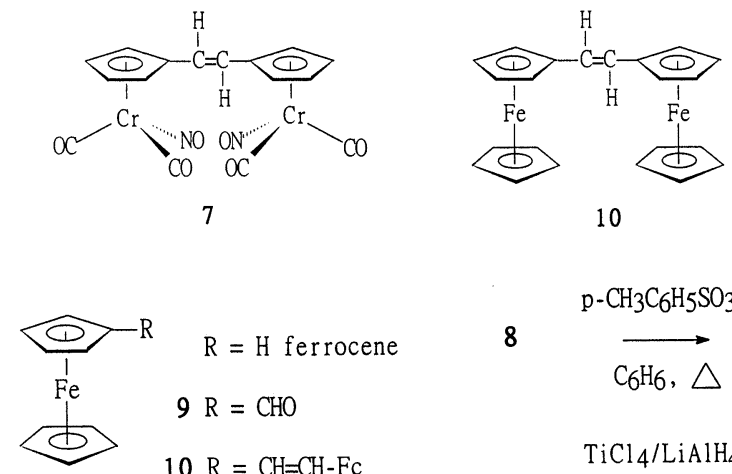

10

8

p- $\mathrm{CH}_{3} \mathrm{C}_{6} \mathrm{H}_{5} \mathrm{SO}_{3} \mathrm{H}$

$\overrightarrow{\mathrm{C}_{6} \mathrm{H}_{6}, \triangle}$

$\mathrm{TiCl}_{4} / \mathrm{LiAlH}_{4}$

3

$\mathrm{TiCl}_{3} / \mathrm{LiAlH}_{4}$

9 10

Table 5

Atomic parameters $x, y, z$ and $B_{\mathrm{eq}}{ }^{a}$ of 7, estimated S.D.s refer to the last digit printed

\begin{tabular}{lclcl}
\hline & \multicolumn{3}{l}{$y$} & \multicolumn{1}{l}{$B_{\text {eq }}$} \\
\hline Cr & $0.25739(9)$ & $0.22020(5)$ & $0.07397(5)$ & $3.40(3)$ \\
N1 & $0.4863(5)$ & $0.2069(3)$ & $0.1757(3)$ & $4.73(17)$ \\
C2 & $0.3740(6)$ & $0.1406(4)$ & $-0.0326(3)$ & $3.88(19)$ \\
C3 & $0.1365(6)$ & $0.0874(4)$ & $0.1225(3)$ & $3.86(19)$ \\
C5 & $0.4368(7)$ & $0.4630(3)$ & $-0.0293(4)$ & $4.13(22)$ \\
C6 & $0.2558(6)$ & $0.4036(3)$ & $0.0092(3)$ & $3.39(18)$ \\
C7 & $0.1003(7)$ & $0.3375(4)$ & $-0.0618(4)$ & $4.28(21)$ \\
C8 & $-0.0516(7)$ & $0.2978(4)$ & $0.0019(5)$ & $5.01(25)$ \\
C9 & $0.0069(7)$ & $0.3390(4)$ & $0.1130(5)$ & $4.83(24)$ \\
C10 & $0.1941(7)$ & $0.4036(4)$ & $0.1175(4)$ & $4.10(21)$ \\
O1 & $0.6377(5)$ & $0.1979(3)$ & $0.1433(3)$ & $6.82(18)$ \\
O2 & $0.4499(5)$ & $0.0924(3)$ & $-0.10142(25)$ & $6.69(18)$ \\
O3 & $0.0628(5)$ & $0.0039(3)$ & $0.1540(3)$ & $6.92(19)$ \\
H5 & $0.519(6)$ & $0.546(3)$ & $0.104(3)$ & $6.1(11)$ \\
H7 & $0.097(5)$ & $0.325(3)$ & $-0.142(3)$ & $3.2(8)$ \\
H8 & $-0.177(6)$ & $0.252(4)$ & $-0.024(3)$ & $7.0(12)$ \\
H9 & $-0.057(5)$ & $0.332(3)$ & $0.180(3)$ & $4.2(9)$ \\
H10 & $0.260(5)$ & $0.437(3)$ & $0.172(3)$ & $2.7(9)$ \\
& & & & \\
\hline
\end{tabular}

${ }^{\mathrm{a}} B_{\text {eq }}$ is the mean of the principal axes of the thermal ellipsoid.
Table 6

Selected bond distances $(\AA)$ and angles $\left(^{\circ}\right)$ of 7

\begin{tabular}{|c|c|c|c|}
\hline \multicolumn{4}{|l|}{ Bond distances } \\
\hline $\mathrm{Cr}-\mathrm{C} 6$ & $2.211(4)$ & $\mathrm{Cr}-\mathrm{C} 7$ & $2.206(4)$ \\
\hline $\mathrm{Cr}-\mathrm{C} 8$ & $2.203(4)$ & $\mathrm{Cr}-\mathrm{C} 9$ & $2.193(4)$ \\
\hline $\mathrm{Cr}-\mathrm{C} 10$ & $2.188(4)$ & & \\
\hline $\mathrm{C} 6-\mathrm{C} 7$ & $1.411(6)$ & $\mathrm{C} 6-\mathrm{C} 10$ & $1.410(6)$ \\
\hline $\mathrm{C} 7-\mathrm{C} 8$ & $1.397(7)$ & $\mathrm{C} 8-\mathrm{C} 9$ & $1.399(8)$ \\
\hline C9-C10 & $1.393(7)$ & $\mathrm{Cr}-\mathrm{N} 1$ & $1.750(4)$ \\
\hline $\mathrm{Cr}-\mathrm{C} 2$ & $1.812(4)$ & $\mathrm{Cr}-\mathrm{C} 3$ & $1.823(4)$ \\
\hline $\mathrm{N} 1-\mathrm{O} 1$ & $1.161(4)$ & $\mathrm{C} 2-\mathrm{O} 2$ & $1.154(5)$ \\
\hline $\mathrm{C} 3-\mathrm{O} 3$ & $1.144(5)$ & $\mathrm{C} 5-\mathrm{C} 6$ & $1.471(6)$ \\
\hline $\mathrm{C} 5-\mathrm{C} 5$ & $1.288(8)$ & & \\
\hline $\mathrm{Cr} \cdots$ centroid $(\mathrm{Cp})$ & 1.849 & $\mathrm{Cr} \cdots \mathrm{C} 5$ & 3.287 \\
\hline $\mathrm{C} 5 \cdots \mathrm{C} 10$ & 3.116 & $\mathrm{H}(\mathrm{C} 5) \cdots \mathrm{H}(\mathrm{C} 10)$ & 3.79 \\
\hline \multicolumn{4}{|l|}{ Bond angles } \\
\hline $\mathrm{C} 6-\mathrm{C} 7-\mathrm{C} 8$ & $109.0(4)$ & $\mathrm{C} 7-\mathrm{C} 8-\mathrm{C} 9$ & $107.8(4)$ \\
\hline $\mathrm{C} 7-\mathrm{C} 6-\mathrm{C} 10$ & $106.1(4)$ & $\mathrm{C} 8-\mathrm{C} 9-\mathrm{C} 10$ & $107.9(4)$ \\
\hline $\mathrm{CO}-\mathrm{C} 10-\mathrm{C} 9$ & $109.1(4)$ & $\mathrm{N} 1-\mathrm{Cr}-\mathrm{C} 2$ & $93.10(17)$ \\
\hline $\mathrm{N} 1-\mathrm{Cr}-\mathrm{C} 3$ & $93.30(17)$ & $\mathrm{C} 2-\mathrm{Cr}-\mathrm{C} 3$ & $93.26(18)$ \\
\hline $\mathrm{Cr}-\mathrm{N} 1-\mathrm{O} 1$ & $179.8(3)$ & $\mathrm{Cr}-\mathrm{C} 2-\mathrm{O} 2$ & $178.4(4)$ \\
\hline $\mathrm{Cr}-\mathrm{C} 3-\mathrm{O} 3$ & $179.1(4)$ & $\mathrm{C} 5-\mathrm{C} 6-\mathrm{C} 7$ & $124.4(4)$ \\
\hline $\mathrm{C} 5-\mathrm{C} 6-\mathrm{C} 10$ & $129.4(4)$ & $\mathrm{C} 5-\mathrm{C} 5-\mathrm{C} 6$ & $125.5(4)$ \\
\hline Centroid $(\mathrm{Cp})-\mathrm{Cr}-\mathrm{N} 1$ & 126.8 & & \\
\hline Centroid(Cp)-Cr-C2 & 120.4 & centroid $(\mathrm{Cp})-\mathrm{Cr}-\mathrm{C} 3$ & 121.6 \\
\hline
\end{tabular}

Compound 7 exhibits two carbonyl stretching bands, the symmetric mode occurring at $2010 \mathrm{~cm}^{-1}$ and the asymmetric mode at $1932 \mathrm{~cm}^{-1}$. The nitrosyl stretching band is observed at $1682 \mathrm{~cm}^{-1}$. It is interesting to compare the three stretching frequencies of 7 with the corresponding bands of its unsubstituted parent compound $1\left(2025,1955 ; 1695 \mathrm{~cm}^{-1}\right)$. The lower-frequency shift by 15,23 and 13 wave-numbers indicate that the vinyl group is exerting as an electron donating group to the two adjacent cynichrodene moieties. The data is consistent with the result found from the study of the ${ }^{13} \mathrm{C}$-NMR spectra.

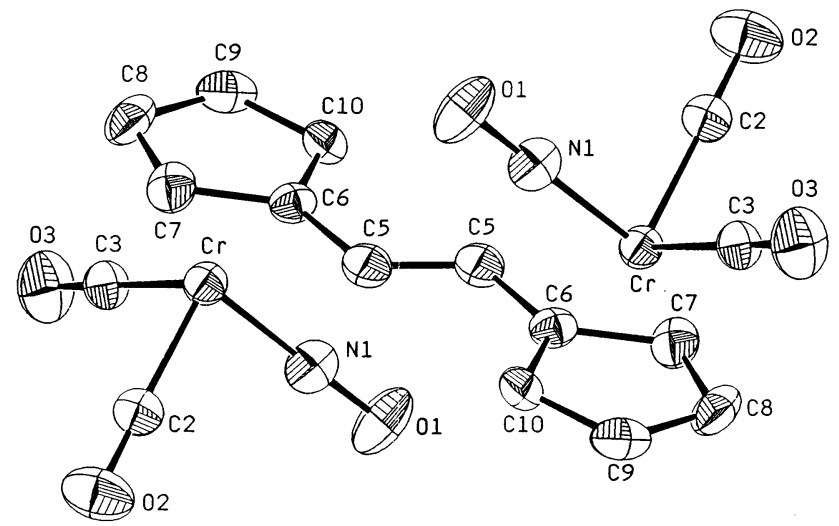

Fig. 2. Molecular configuration of 7. 


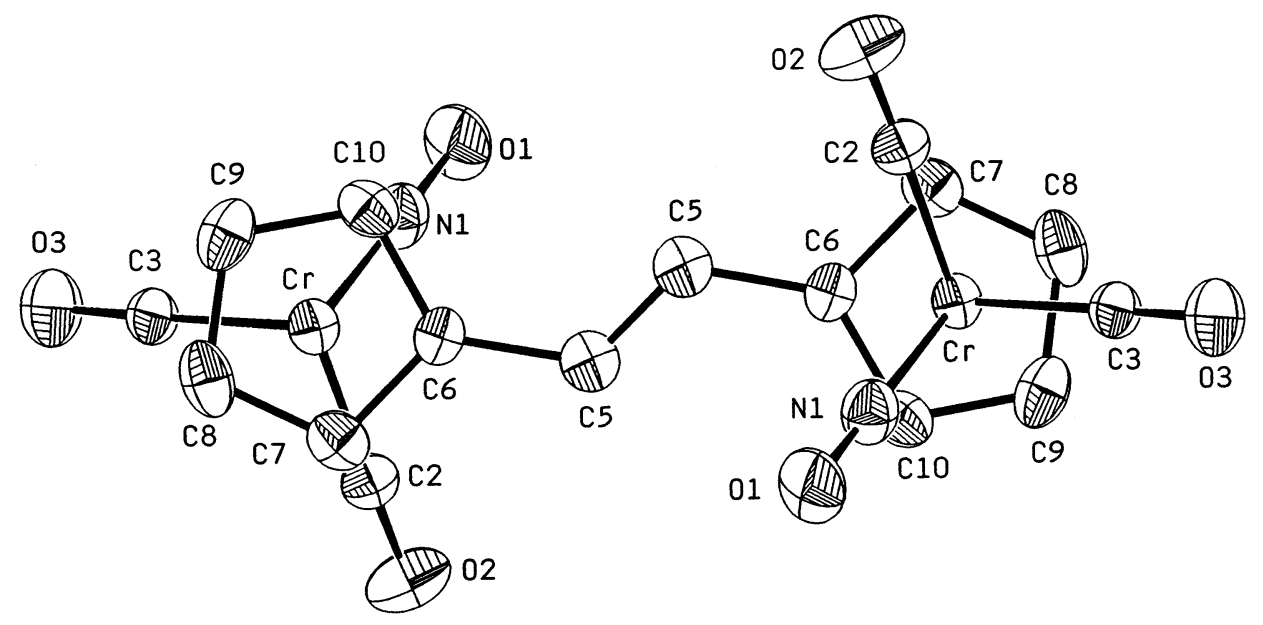

Fig. 3. View of 7 along the normal of $\mathrm{Cp}(\mathrm{Cr})$ ring.

The ${ }^{1} \mathrm{H}-\mathrm{NMR}$ spectra of $\mathbf{6}, \mathbf{7}$, and $\mathbf{1 0}$ were consistent with their structures and similar to other metallocenyl systems [12,13]. The strong diamagnetic anisotropic effect of the vinyl group on the ring protons might explain why the protons (2- and 5-positions) closer to it were deshielded to a greater extent than those (3- and 4-positions) further away from it.

From Table 2, the contracted 2D HetCOR spectra of 2-7 (Fig. 1), it is interesting to find that compounds 2-4 exhibit positive slopes, while 6 and 7 exhibit negative slopes. The opposite slopes may be interpreted as follows. First, the strong diamagnetic anisotropic effects of the carbonyl and vinyl group on the ring protons might explain why the protons (2- and 5-positions) closer to it were deshielded to the lower field for all compounds of 2-4 and 6-7. These results are in agreement with the corresponding benzene and ferrocene analogues (Table 3 ). Second, the shielding of $C(2,5)$ and $C(3,4)$ carbons atoms of 6 and 7 are analogous to $\mathbf{5}$ instead of $\mathbf{2}-\mathbf{4}$ and suggests that the electron density distribution in the cyclopentadienyl rings of $6-7$ is similar to 5 , rather than $2-\mathbf{4}$.

The assignment of ${ }^{13} \mathrm{C}-\mathrm{NMR}$ spectra of $\mathbf{6}, \mathbf{7}$, and $\mathbf{1 0}$ were based on standard ${ }^{13} \mathrm{C}-\mathrm{NMR}$ correlations [14], 2D HetCOR(Table 2), the DEPT technique and by comparison with other metallo-aromatic systems [15].

It is interesting to compare the ${ }^{13} \mathrm{C}-\mathrm{NMR}$ spectra of $\mathbf{3}, \mathbf{6}$, and $\mathbf{7}$ with their unsubstituted parent compound $\mathbf{1}$ (Table 4). For the carbon atoms on $\mathrm{Cp}(\mathrm{Cr})(\mathrm{C}(3,4)$ and $\mathrm{C}(2,5))$, the chemical shifts of $\mathbf{3}$ occur at a lower field than the chemical shifts of 1 at $\delta=90.31 \mathrm{ppm}$. However, the chemical shifts of $\mathbf{6}$ and 7 occur at a higher field than $\delta=90.31 \mathrm{ppm}$. This reflects the strong electron-withdrawing effect of the formyl group on $\mathbf{3}$ and the strong electron-donating effect of vinyl group on $\mathbf{6}$ and 7. It is worth pointing out from Table 4 that the chemical shifts of $\mathrm{C}(3,4)$ occur at a higher field than the chemical shifts of $\mathrm{C}(2,5)$ for $\mathbf{3}$ and $\mathbf{4}$. On the contrary, the chemical shifts of $\mathrm{C}(3,4)$ occur at a lower field than the chemical shifts of $C(2,5)$ for 5-7. Earlier, we have reported thorough spectra studies on aminocynichrodene (5) [2], a compound with a strong electron-donating substituent, $-\mathrm{NH}_{2}$ on $\mathrm{Cp}$. We also compared the chemical shifts of selected monosubstituted cynichrodene derivatives with the NMR data of their analogues of ferrocene and benzene derivatives (Table 4). The large contribution of canonical form 5a to 5 explained the relatively large negative difference $\Delta(-11.2)$ in $C(2,5)$ and $C(3,4)$. This is understandable in the stabilization of chromium anion because of the overall electron-withdrawing properties of CO and NO ligands.

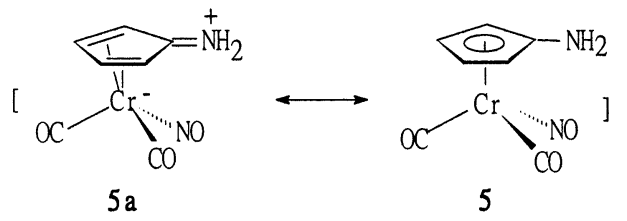

As is well known, the vinyl group can exert an either electron-donating or electron-withdrawing effect by resonance to its attached group. When an electron-donating group is attached to it, the vinyl group withdraws the electron from the group, and vice versa.

Upon examination of the infrared spectra of 6 and 7 (Tables 2 and 4), the following conclusions may be drawn:

1. the vinyl group exerts the same kind of electronic effect as the amino group, rather than carbonyl group, to its adjacent $\mathrm{Cp}$ ring;

2. in compounds 6 and 7, the vinyl group donates electrons to the adjacent $\mathrm{Cp} \operatorname{ring}(\mathrm{s})$, which in turn transfers the electron density to the metal chromium. This resulted in an enhanced $\pi$-back bonding phenomena observed in IR spectra;

3. canonical $7 \mathbf{a}$, rather than $\mathbf{7 b}$, to some extent contributes to the structure of 7 . 
Table 7

Selected structural data of $\mathbf{7 , 1 2}$ and $13^{\mathrm{a}}$

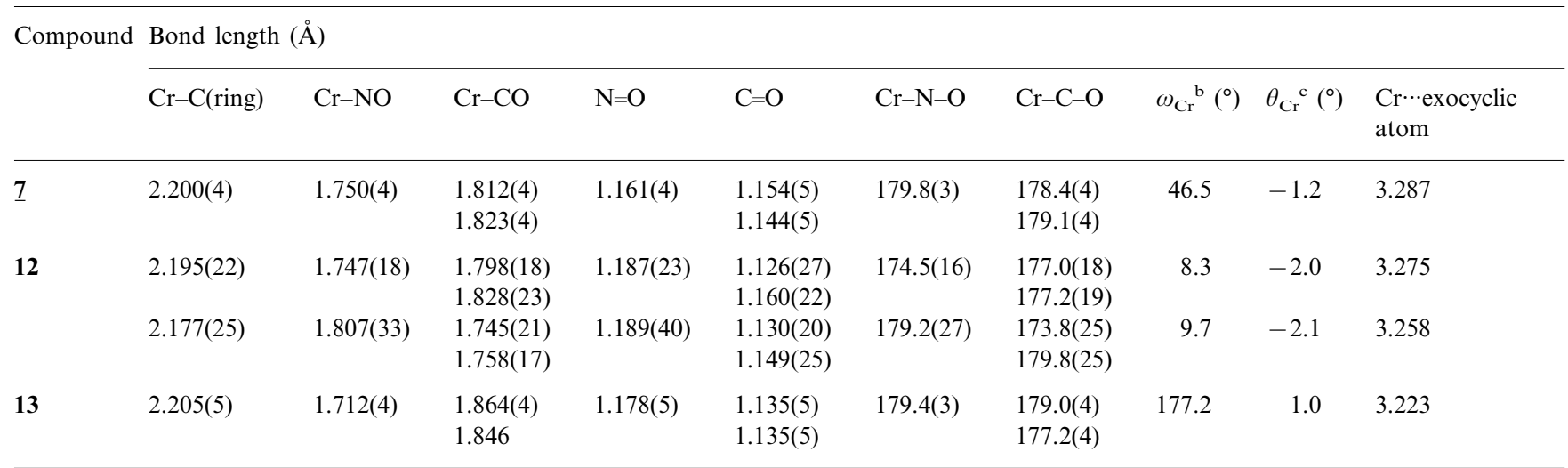

\footnotetext{
a $12(\mathrm{CO})_{2}(\mathrm{NO}) \mathrm{Cr}\left[\left(\eta^{5}-\mathrm{C}_{5} \mathrm{H}_{4}\right)-\mathrm{NH}-\mathrm{C}(\mathrm{O})-\mathrm{NH}-\left(\eta^{5}-\mathrm{C}_{5} \mathrm{H}_{4}\right)\right] \mathrm{Fe}\left(\eta^{5}-\mathrm{C}_{5} \mathrm{H}_{5}\right) ; 13(\mathrm{CO})_{2}(\mathrm{NO}) \mathrm{Cr}\left(\eta^{5}-\mathrm{C}_{5} \mathrm{H}_{4}\right) \mathrm{C}(\mathrm{O})\left(\eta^{5}-\mathrm{C}_{5} \mathrm{H}_{4}\right) \mathrm{Fe}\left(\eta^{5}-\mathrm{C}_{5} \mathrm{H}_{5}\right)$.

${ }^{\mathrm{b}} \omega_{\mathrm{Cr}}\left({ }^{\circ}\right)$ : the twist angle is defined as the torsional angle between the nitrosyl nitrogen atom, the chromium atom, the $\mathrm{Cp}$ center and the ring carbon atom bearing the exocyclic carbon atom.

${ }^{\mathrm{c}} \theta_{\mathrm{Cr}}\left({ }^{\circ}\right)$ : the angle $\theta$ is defined as the angle between the exocyclic bond and the corresponding $\mathrm{Cp}$ ring with positive angle towards metal and negative angles away from the metal.
}
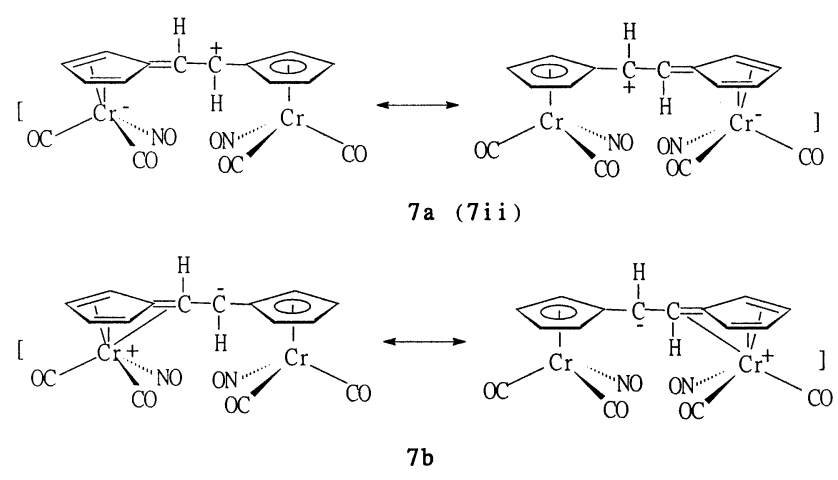

The molecular structure of 7 is shown in Fig. 2. The atomic coordinates of the non-hydrogen atoms are listed in Table 5. Selected bond distances and angles are given in Table 6 .

Compound 7 adopts a transoid conformation at the organic vinyl carbons. The coordination geometry about the $\mathrm{Cr}$ center is approximately a distorted tetrahedron with two carbonyl groups, the Cp group and nitrosyl group as the four coordination sites. The nitrosyl group is located at the side toward the exocyclic carbon atom of $\mathrm{Cp}\left(\mathrm{Cr}\right.$ ) with a twist angle of $46.5^{\circ}$ (Fig. $3)$. The twist angle is defined as the torsional angle between the nitrosyl nitrogen atom, the chromium atom, the $\mathrm{Cp}$ center and the ring carbon atom bearing the exocyclic carbon atom.

In the cynicrodene moiety, the observed average bond length of $\mathrm{Cr}-\mathrm{C}$ (ring) is $2.200(4) \AA$. The $\mathrm{Cr}-\mathrm{N}$ length of $1.750(4)(\mathrm{Cr}-\mathrm{N} 1)$ is closer to those found in $(\mathrm{CO})_{2}(\mathrm{NO}) \mathrm{Cr}\left[\left(\eta^{5}-\mathrm{C}_{5} \mathrm{H}_{4}\right)-\mathrm{NH}-\mathrm{C}(\mathrm{O})-\mathrm{NH}-\left(\eta^{5}-\mathrm{C}_{5} \mathrm{H}_{4}\right)\right]$
$\mathrm{Fe}\left(\eta^{5}-\mathrm{C}_{5} \mathrm{H}_{5}\right)$ (12) [2](1.747(18), 1.803(33) $\AA$ ) than the values found in $(\mathrm{CO})_{2}(\mathrm{NO}) \mathrm{Cr}\left(\eta^{5}-\mathrm{C}_{5} \mathrm{H}_{4}\right) \mathrm{C}(\mathrm{O})\left(\eta^{5}\right.$ $\left.\mathrm{C}_{5} \mathrm{H}_{4}\right) \mathrm{Fe}\left(\eta^{5}-\mathrm{C}_{5} \mathrm{H}_{5}\right)(\mathbf{1 3})(1.712(4) \AA)$ [1]. The $\mathrm{Cr}-\mathrm{C}$ (carbonyl) distances of 1.812(4) $\mathrm{\AA}(\mathrm{Cr}-\mathrm{C} 2)$ and 1.823(4) $\AA$ $(\mathrm{Cr}-\mathrm{C} 3)$ are between those found in $\mathbf{1 2}$ (average 1.782(23) ̊) [2] and those found in $\mathbf{1 3}$ (average 1.855(4) $\AA$ ) [1]. The $\mathrm{Cr}-\mathrm{N}-\mathrm{O}$ angle of $179.8(3)^{\circ}$ is consistent with the $\mathrm{NO}^{+}$formalism typical of the linear $\mathrm{M}-\mathrm{NO}$ linkage. The $\mathrm{Cr}-\mathrm{C}-\mathrm{O}$ angles of $178.4(4)^{\circ}(\mathrm{Cr}-\mathrm{C} 2-\mathrm{O} 2)$ and $179.1(4)^{\circ}(\mathrm{Cr}-\mathrm{C} 3-\mathrm{O} 3)$ indicate the usual mode of bonding in the terminal metal carbonyl complexes. The $\mathrm{Cr}$-centroid $(\mathrm{Cp}(\mathrm{Cr}))$ distance of $1.849 \AA$ agrees with the values of $1.843 \AA$ in 12 [2] and $1.846 \AA$ in 13 [1]. The average $\mathrm{C}-\mathrm{C}$ distance in the ring $(\mathrm{Cp}(\mathrm{Cr}))$ is 1.402 $\AA$. Selected structural data of 7, 12 and $\mathbf{1 3}$ are listed in Table 7.

The exocyclic $\mathrm{C}=\mathrm{C}$ bond length is $1.228(8) \AA$ (C5$\mathrm{C5}$ ). The exocyclic carbon atom $\mathrm{C} 5$ is bent away from the corresponding $\mathrm{Cr}$ atom, with an angle $\theta=-1.2^{\circ}$. The angle $\theta$ is defined as the angle between the exocyclic $\mathrm{C} 6-\mathrm{C} 5$ bond and the corresponding $\mathrm{Cp}$ ring with positive angle towards metal and negative angle away from the metal. The vinyl plane turns away from the ring planes by $9.1^{\circ}$. The two $\mathrm{Cp}$ planes are coplanar.

Upon examination of the bonds of $\mathrm{Cr}-\mathrm{NO}, \mathrm{Cr}-\mathrm{CO}$, $\mathrm{N}=\mathrm{O}$, and $\mathrm{C}=\mathrm{O}$, it is interesting to find that 7 has the longer bond distances of $\mathrm{Cr}-\mathrm{NO}$ and $\mathrm{C}=\mathrm{O}$, while it has the shorter bond distances of $\mathrm{Cr}-\mathrm{CO}$ and $\mathrm{N}=\mathrm{O}$ than $\mathbf{1 3}$ (Table 5). The contributions of canonical form 7ii to 7 and 13i to 13 may explain such results. 


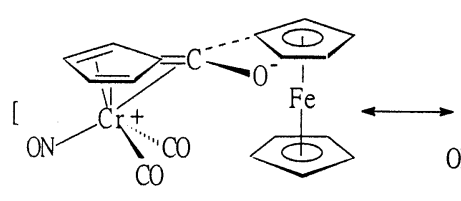

$13 \mathrm{i}$

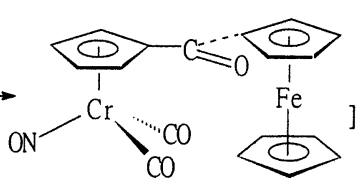

13

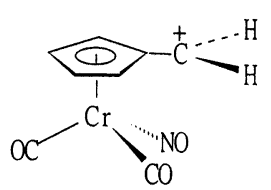

14
Previously, McGlinchey [16] made EHMO calculations on compound $\left[(\mathrm{CO})_{2}(\mathrm{NO}) \mathrm{Cr}\left(\mathrm{C}_{5} \mathrm{H}_{4}-\mathrm{CH}_{2}\right)\right]^{+}$(14). The symmetric isomer $\mathbf{1 4 i}$ is favored by $2.7 \mathrm{kcal} \mathrm{mol}^{-1}$ over the unsymmetrical rotamer 14ii.

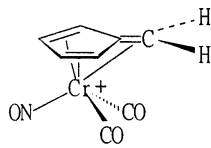

$14 \mathrm{i}$

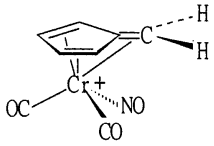

$14 \mathrm{i}$ i

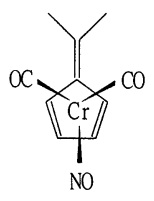

i

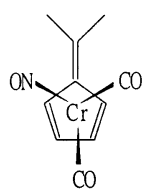

i i
The calculation is consistent with the $\mathrm{X}$-ray structure of 13, a compound with its $\mathrm{Cp}$ rings bearing an electron-withdrawing group. The twist angle of $\mathbf{1 3}$ is $177.2^{\circ}$ (Fig. 5, Table 7). The preference for the symmetrical isomer of 13i is related to the ability of the exocyclic double bond to donate electron density to the chromium atom such that it is trans to the better $\pi$-accepting ligand, i.e. $\mathrm{NO}^{+}$. As a result, the shorter bond distance of $\mathrm{Cr}-\mathrm{NO}$ and the longer bond distance of $\mathrm{N}=\mathrm{O}$ are observed. Conversely, for compound 7, its $\mathrm{Cp}$ rings bearing an electron-donating group, the unsymmetrical rotamer 7ii having a longer $\mathrm{Cr}-\mathrm{NO}$ and shorter $\mathrm{N}=\mathrm{O}$ bond distances is preferred.

The X-ray structural data also support the EHMO calculation. In 7 a negative $\theta$ value $\left(-1.2^{\circ}\right)$ and a longer bond distance between chromium atom and exocyclic carbon $(3.287 \AA$ ) was obtained; while a positive $\theta$ value $\left(1.04^{\circ}\right)$ and a shorter bond distance between chromium atom and exocyclic carbon $(3.223 \AA)$ was obtained in 13. The molecular structures of $\mathbf{1 2}$ and $\mathbf{1 3}$ are shown in Figs. 4 and 5, respectively.

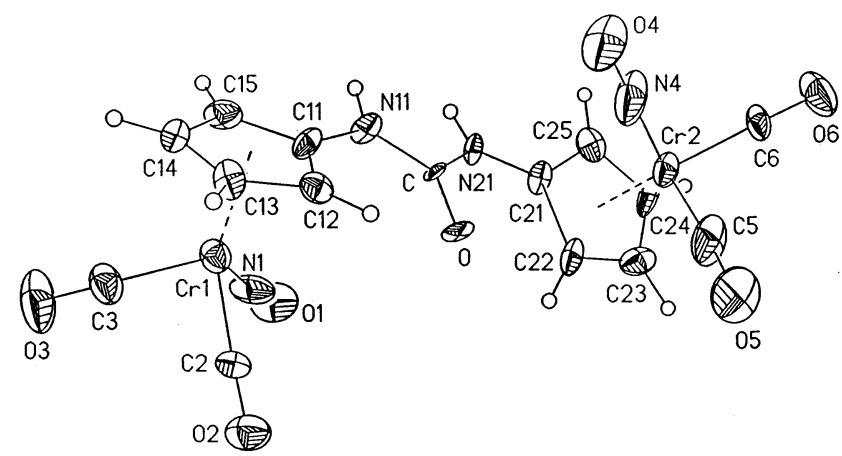

Fig. 4. Molecular configuration of $\mathbf{1 2}$.

\section{Supplementary material available}

A list of anisotropic temperature factors of non-hydrogen atoms and the coordinates with isotropic temperature factors of hydrogen atoms as well as list of structure amplitudes (6 pp.) have been deposited. Ordering information can be obtained from the authors.

\section{Acknowledgements}

The authors are grateful to the National Science Council of Taiwan for grants in support of this research program.

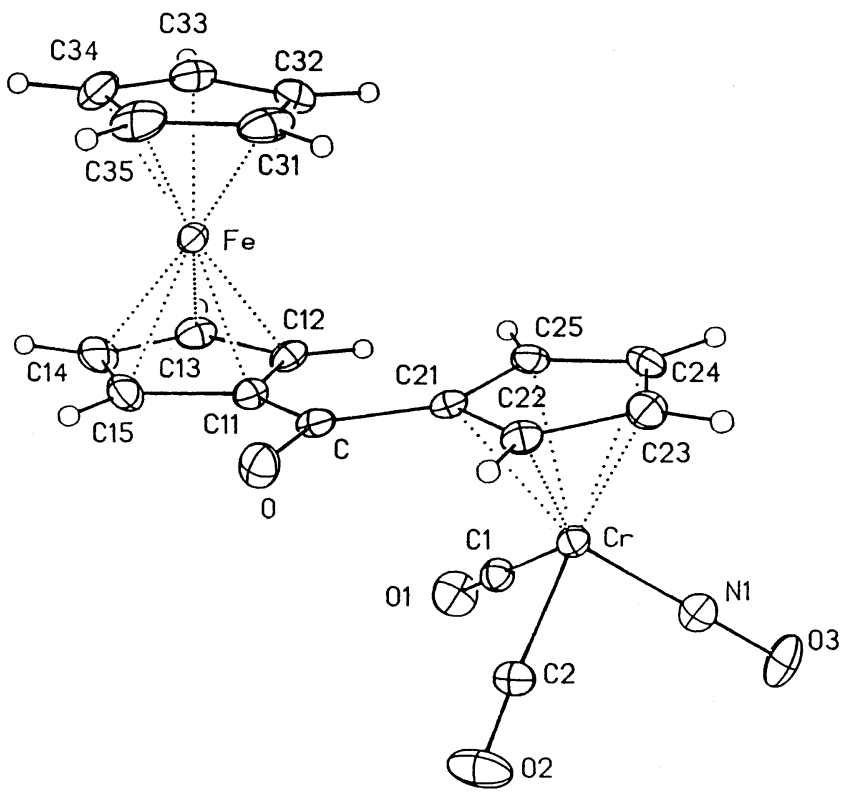

Fig. 5. Molecular configuration of $\mathbf{1 3}$.

\section{References}

[1] Y.-P. Wang, J.-M. Hwu, S.-L. Wang, J. Organomet. Chem. 371 (1989) 71.

[2] Y.-P. Wang, T.-S. Lin, Y.-H. Yang, J.-H. Liaw, S.-L. Wang, F.-L. Liao, Y.-J. Lu, J. Organomet. Chem. 503 (1995) 35.

[3] J.E. McMurry, Chem. Rev. 89 (1989) 1513.

[4] J.E. McMurry, M.P. Fleming, J. Amer. Chem. Soc. 96 (1974) 4708 .

[5] A. Kasahara, T. Izumi, Chem. Lett. (1978) 21.

[6] D.W. Macomber, M.D. Rausch, Organometallics 2 (1983) 1523.

[7] P.J. Graham, R.V. Lindsey, G.W. Parshall, M.L. Peterson, G.M. Whitman, J. Am. Chem. Soc. 79 (1957) 3416. 
[8] C.U. Pittman Jr., T.D. Rounsefell, E.A. Lewis, J.E. Sheata, M.D. Rausch, E.A. Mintz, Macromolecules 11 (1978) 560.

[9] M.D. Rausch, A. Siegel, J. Organomet. Chem. 11 (1968) 317.

[10] Scattering factors from Int. Tab. Vol. 4: International Tables for X-ray Crystallography, Vol. IV, Kynoch, Birmingham, England, 1974.

[11] Full system reference: E.J. Gabe, Y. LePage, J.-P. Charland, F., L. Lee, P.S. White, J. Appl. Crystallogr. 22 (1989) 384.

[12] M.D. Rausch, E.A. Mintz, D.W. Macomber, J. Org. Chem. 45 (1980) 689.

[13] E.W. Slocum, C.R. Ernst, Adv. Organomet. Chem. 10 (1972) 79.
[14] J.B. Stotter (Ed.), Carbon-13 NMR Spectroscopy, Academic Press, New York, 1972.

[15] B.E. Mann, Adv. Organomet. Chem. 12 (1974) 135.

[16] P.A. Downton, B.G. Sayer, M.J. McGlinchey, Organometallics 11 (1992) 3281.

[17] R.M. Silverstein, G.C. Bassler, T.C. Morrill, Spectrometric Identification of Organic Compounds, Wiley, New York, 1981.

[18] M.D. Rausch, D.J. Kowalski, E.A. Mintz, J. Organomet. Chem. 342 (1988) 201.

[19] E. Breitmaier, W. Voelter, Carbon-13 NMR Spectroscopy, VCH, New York, 1987. 